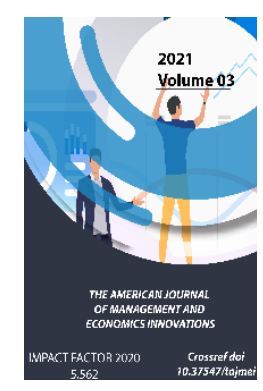

\title{
Directions Of Using Foreign Experience In The Provision Of Ecological Tourism Services In The Economy
}

\author{
Mohigul Erkinovna Ahtamova \\ Senior Lecturer, Samarkand Institute Of Economics And Service, Uzbekistan
}

Journal Website:

https://theamericanjou

rnals.com/index.php/ta

jmei

Copyright: Original

content from this work

may be used under the

terms of the creative

commons attributes

4.0 licence.

\section{ABSTRACT}

In the development of ecotourism in our country, the use of international environmental models requires, first of all, knowledge of the objects of use, compiling a list and a thorough study of the possibilities of use. Therefore, the features, models, development factors and the socio-economic essence of ecotourism have been investigated. The state of tourism development, potential and level, as well as organizational and economic mechanisms for the development of ecotourism in foreign countries have been analyzed.

\section{KEYWORDS}

Ecotourism, models, national parks, foreign experience, provision of ecological tourism.

\section{INTRODUCTION}

There are no unique models or methods of ecotourism development in the world that are directly compatible with the natural conditions of each country and the use of tourist resources in them. However, the use of national parks and state reserves in the development of ecotourism is well studied. From this point of view, it is necessary to focus on the concept, content and essence of national parks. This is because national parks play a standard role in the development of ecotourism. National parks are natural complexes that comprehensively protect the natural landscape and its biodiversity, one or several ecosystems, create opportunities for recreation, create and support each other in ecotourism in many countries of the world. 


\section{MATERIAL AND METHODS}

There are currently 3,400 national parks in the world. There are many methods, techniques and models for the use of national parks in the world. Such models are still being invented. In many cases, the use of national parks in ecotourism around the world is preceded by private funding. In some cases, the idea is growing that the use of national parks in ecotourism should be based solely on private property. It should be recognized that the use of national parks in ecotourism in the world is carried out in three different ways:

1. National parks are state property.

2. National parks are public and private property.

3. National parks are in mixed ownership (state, private, state).

It should be noted that the main goal of ecotourism is to spend money on outdoor recreation, and the local budget - on nature conservation, that is, to pay the entrance tax for outdoor recreation. National parks, developing on the basis of national sources of funding, live mainly from state sponsors (industrial enterprises, firms, concerns and individuals, the city, the state budget and the budget ...). Today the number of such countries in the world has exceeded 30 . Their annual income is $\$ 1$ billion. dollars. National parks, which come from local sources, are funded mainly by the benefits of ecotourism. The use of national parks in ecotourism brings Canada $\$ 250$ million per year and the US $\$ 870$ million per year.

Likewise, Japan's national parks are visited by 316 million ecotourists every year. Of these, 252.8 million UAH. Japanese - 6.2 million foreign ecotourists. At the moment there are 4 models of national parks. The division of these models into separate models is based on their own characteristics:

1. American model.

2. European model.

3. Model of the park.

4. Asian model

RESULTS

We must use these models in the development of ecological tourism in our country.

1. The model of American national parks is characterized by a very large unique nature of protected areas. For example, Greenland National Park - 70 million. Kalahari Central Park in Africa - 5.2 million, Alaska National Park in the US - 7.3 million, Bad Buffalo in Canada - 4.4 million, Gobi National Park in Mongolia - 5 million, Colima National Park in Russia - 3 million hectares ...

According to this model, the United States was the first to establish a national park. In 1872 , the US government established what is now the world famous Yellowstone National Park. The United States and Canada have used this model to expand the size of national parks within their borders, despite increasing human activity. To date, the state of Canada has expanded its national parks by $12 \%$. These national parks are state owned and in some cases leased to large corporations, but the state retains the right to oversee the conservation of the national park. Funding for national parks in this model is very large. Both the state and the federal states contribute to the conservation of the national parks. In addition, private owners contribute (half of the recreational services in national parks are in the 
private sector). Thus, the typical national parks of North America are the richest national parks in the world.

2. European model. The first European national park was founded in 1909 in Sweden. The unique advantages of this model were developed in the UK. The work on this model has been established and is being developed in Western Europe and Japan. The main features of this model are the small size of national parks and a high level of ecological knowledge and culture of the population. Funding for this model is provided by the state. Therefore, the infrastructure of transport, road communications and ecotourism is organized at a very high level.

Another feature of national parks in the European model is that nearly $50 \%$ of national parks are in the private sector. The biggest motto of the national parks is to restore the health of the population and create conditions for recreation, so the influx of domestic ecotourists is very large, but the influx of external ecotourism is also great.

Considering the environment and conditions for the formation of national parks in European countries, we must first of all pay attention to the fact that Europeans are far ahead of the rest of the world in socio-economic development. They received the awareness that their population lives on the most densely populated continent, thanks to scientific and technological progress, and secondly, the high level of socio-political consciousness and culture of people living in this country, their commitment to nature conservation and their growing global environmental problems.

3. The concept of the development of the reserve-park model is completely different - financing of national parks is carried out not at the expense of the state, but for the support of the state. The main principle of these national parks is self-confidence, the idea is self-sufficiency. This model was formed in the middle of the twentieth century and is now widespread in developing countries. Entrance fees to the national park are very low, which is why local and foreign tourists visit it often.

The most important factor in the reserve park model is determined by the fact that Europeans have a very high level of ecological awareness and ecological culture. This is essential for the operation of the national park system. That is, decades have passed since the Europeans adopted the slogan "Keep your home clean."

4. The Asian model is currently in the process of being formed. The management of national parks in this model is mainly stateowned. Asian countries are serious about creating or exploring the use of national parks and protected areas in the development of ecological tourism, which is developing internationally in their domestic tourism, providing important prospects for the protection of the environment and the socio-economic life of the local population. As noted above, the Asian model of ecotourism development is just beginning to develop. Among Asian countries, India, Thailand, South Korea and Japan are among the countries that have been developing ecological tourism for many years.

5. The Australian Model. An analysis of the scientific literature shows that Australia is the world's leading ecotourism-based country and the development of ecotourism in the world on the basis of scientific and practical principles. When the state organizes ecological tourism on the 
territory of its state, it develops state programs for the socio-economic development of regions and studies the possibilities of developing ecotourism, taking into account the natural resources of the region.

\section{DISCUSSION}

Most importantly, the socio-economic interests of the local indigenous population are taken into account when organizing ecotourism, and the implementation of ecotourism services is fully entrusted to them. Secondly, the proposals and recommendations of the state administrations of the country have been fully taken into account. One of the most important factors in the success of the Australian model is that ecotourism services organized in all regions are provided only by the local population of the region. This work solves the problem of employment of the local population and helps to timely solve the socioeconomic problems of local villages.

Many scientists often refer to the Galapagos Islands as the birthplace of ecotourism: Europeans first visited these islands 150 years ago. This archipelago is one of the most unusual and unique ecosystems on Earth.3 50\% of birds, $50 \%$ of insects, a third of plants and almost all reptiles that live in this area belong only to the Galapagos Islands and do not belong to them. found in other regions.

Since the 1960s, scientific research has led to the development of effective conservation methods for the Galapagos Islands. But since the late 1980s, the Galapagos Islands have had to face many difficult challenges following the ecotourism boom - migrants, new species, industrial upheavals, unemployment and development interests, and garden management. Despite the passage of a special law for the Galapagos Islands in 1998, environmental legislation has been a subject of controversy for many years: the number of Galapagos residents and the number of tourists visiting the Galapagos has doubled over the past decade.

Ecotourism, in turn, has resulted in a complex set of interactions. Ecotourism revenues can help conserve, research, and manage parks. Ecotourism provides tourists with useful information about the importance of the archipelago. Ecotourism revenues are used to develop the Galapagos economy and preserve the environment5. However, as a result of ecotourism, the influx of immigrants to these islands has also increased and threatened the environment.

Today, the Galapagos Islands are losing their reputation as the world's oldest ecotourism destination. In 1859, Darwin formulated his theory of the evolution of natural selection based on observations made in the Galapagos Islands, it was concluded that all living things adapt and evolve to the environment. Darwin's research led to the mapping of the Galapagos Islands. According to Kurt Vonnegut, "Darwin did not change the Galapagos Islands, but changed the way people think about the island."

Even before Darwin's arrival, the damage to nature caused by human activities on the island intensified. For example, many species of flora and fauna have become endangered due to overfishing by humans and destruction of plants by molars of livestock. The island especially attracted people as a hunting area for giant turtles. Because of this, by the beginning of the 2oth century, a species of turtles called Floreana disappeared.

Costa Rica is another ecotourism center. Since the mid-1980s, this small Central American country has evolved from a secret US war 
against Nicaragua and a testing ground for USAID's free trade and privatization policies to a green tourism laboratory. In particular, the 1987 Nobel Peace Prize awarded by President Oscar Arias Sánchez propelled Costa Rica onto the world stage, cementing its reputation as a peaceful country and pioneering the development of ecotourism.

In the 1990s, Costa Rica ranked first in ecotourism, ahead of older tourist destinations such as the Galapagos Islands, Kenya and Nepal. In 1992, the US Adventure Travel Association named Costa Rica "the number one ecotourism destination in the world." A survey by the Government of Costa Rica found that the majority of tourists came to Costa Rica for reasons related to ecotourism.

According to statistics, Costa Rica's natural wonders cover 5 percent of the world's biodiversity on just 0.035 percent of the world's surface.

Costa Rica has a higher standard of living and literacy than other countries in Latin America. Well-known scientists and environmental organizations work in the country, more than a hundred local and international environmental NGOs have branches.

Costa Rica is a very compact country with a well-developed infrastructure. Well-managed ecotourism that attracts people to Costa Rica a. In 2005, 61 percent of visitors visited national parks, 66 percent watched nature and wildlife, and over 77 percent went to the beach. Other activities include: visiting volcanoes (50 percent), canopy (41 percent), diving (23 percent), rafting ( 9 percent), and swimming (18 percent).

In the 1960s and 1970s, Costa Rican entrepreneurs began building hotels and recreational areas for the middle and upper classes. Since 1980, special attention has been paid to the development of ecotourism infrastructure. During this period, the number of tourists from North America and Europe increased. domestic tourism and the proportion of visitors from other Central American countries declined.

In 1984, the Costa Rican government passed legislation encouraging investment in hotels, air and sea transport companies, car rental agencies and travel agencies. Since the mid1940s, most of the shares of LACSA, the national airline of Costa Rica, have been gradually sold to investors in Japan and El Salvador, and the state's share has dropped to 3 percent. Following the enactment of the Tourism Promotion Act in 1985, tourism projects were eligible for concessions and tax breaks.

President Jose Maria Figueres (1994-1998) has declared ecotourism to be one of the best business opportunities in Costa Rica. It offered various perks to tourism investors, and the US and Canada launched a \$ 15 million advertising campaign to attract ecotourists. But despite a lofty environmental plan, Figueres decided in mid-1995 to give Papagayo the green light, a \$ 3 billion mega-project - the largest project in Central America - the antithesis of green development. Papagayo is called the Cancun of Costa Rica: a huge traditional resort complex with luxury hotels, holiday homes, shopping centers, restaurants, golf courses is built here.

Tanzania is one of the poorest countries in the world. We can say that this country is the richest in wildlife, elephants, lions, zebras, antelopes and many other large mammals are more common than in other African countries. About 3 million animals live in 14 national parks. The 14,763 square kilometer Serengeti Nature Reserve is home to the world's largest concentration of wildlife. Outside the 
Serengeti, there is a famous archaeological site known as the Olduvai Gorge. Other world famous parks include the snow-capped Kilimanjaro National Park, Mount Kilimanjaro at 5,895 meters $(19,341 \mathrm{ft})$, the highest peak in Africa, and Lake Manyara National Park, famous for its flamingos and lions. There are also about twenty-five reserves for which tourists are licensed to hunt. These include the Selous Game Reserve, the largest wildlife area in Africa and the largest herd of elephants on the continent.

Overall, the government estimates that over 25 percent of Tanzania is protected. 5 Four reserves - Serengeti, Ngorongoro Crater, Mount Kilimanjaro and Selous - have been designated by the United Nations as a World Heritage Site of Outstanding Universal Value.

Tourism currently accounts for about 15 percent of Tanzania's entire economy, second only to agriculture. Tanzanian National Parks are marketed as outdoor and adventure destinations. The history of Tanzania's national parks and reserves has always been closely associated with tourism. Initially, tourism was about hunting. Today it is recognized as the most developed ecotourism destination in the world.

Zanzibar is one of the most developed ecotourism countries in the world. In 2000, the Stone Town of Zanzibar was inscribed on the UNESCO World Heritage List, and its remarkable cultural heritage was recognized as one of the most important shopping centers on the Swahili coast in the 19th century. The charm of a rock town, the island's pristine beaches, magnificent cliffs, new marine conservation projects and high-level international festivals are important in attracting the attention of the world community and increasing the number of tourists. In 2004, Zanzibar was voted Best Island Destination.

Despite periodic political violence in Zanzibar and the island's periodic threat from Islamic terrorists, the number of foreign tourists has increased fivefold over the past two decades. Tourists from Italy, Great Britain, other countries of Europe and America make up 65 percent of the total number of tourists.

\section{CONCLUSION}

The positive impact of ecotourism on the state economy is reflected in the comprehensive development of ecotourism in the country, the creation of new jobs, creating additional income in nature conservation. In other words, the economic efficiency of ecotourism reflects the need to develop in parallel with other sectors of the national economic complex in the country and its economic potential.

Tourism is directly involved in the creation of national income of the country. The share of tourism in national income: $4.6 \%$ in Germany, $10 \%$ in Switzerland. The contribution of tourism to the country's economy includes direct and indirect contributions. The direct impact of tourism on the economy of the country (region) is the result of the cost of tourism services and goods. The money spent by tourists in the accommodation brings income, which leads to a chain reaction: expenses income - expenses - income and so on.

This process means the indirect impact of tourism on the economy of the country (region). Tourism creates a secondary demand for goods and services. The indirect contribution of tourism to the country's economy is reflected in the repetitive effects of the purchase of services and goods by tourists at a given time and place. This effect is called the "multiplier effect" or "multiplier" .The 
multiplier is the deviation from the equilibrium of net national product (excluding deductions for capital consumption of gross national product) and the initial change in investment costs, which is the ratio of net net national product to change.

Exports of tourism services mean active tourism for the country's economy, while imports mean passive tourism. The relationship between the cost of a tourist product sold to foreign tourists in the host country and the cost of a tourist product sold abroad by citizens of a particular country is the tourist balance of a particular country.

\section{REFERENCES}

1. Mirziyoyev Sh.M. Address of the President of the Republic of Uzbekistan Shavkat Mirziyoyev to the OliyMajlis // People's speech, January 25, 2020.

2. Tukhliyev N., Abdullayeva T. Ekologicheskiy turizm; suschnost', tendentsii i strategiya razvitiya [Ecoᄀlogical tourism; essence, trends and development strat-egy]. Tomsk, 2009. 415 p. (In Russ.).

3. Haitboyev R. Ekologik turizm [Ecologic tourism]. Samarkand, 2018. 248 p. (In Uzbek.).

4. Alimova M.T. Tourism cluster as an effective organizational and economic mechanism to increase regional competitiveness.// Materials of the Republican IAC on "Actual problems of economic development in the context of modernization of the country" (February 17, 2012), Samarkand, SamISI, 2012. - pp. 178-182.

5. T.K.Sergeva. Ekologik turizm. M.: Finansi va statistika, 2014. - 360 s. - ISBN 5279028193.

6. M.Honey (2008). Ecotourism and sustainable development. Island Press. 2nd edition. Pp.33-34.
7. https://www.unwto.org/glossary-tourismterms.

8. https://lex.uz/docs/4143188.

9. https://ecotourism.org/.

10. https://www.iucn.org/resources/publicatio ns. 